\title{
Catecholamines and free fatty acids in plasma of patients undergoing cardiac operations with hypothermia and bypass
}

\author{
J. HiRVONEN, PIRKKO HUTTUNEN, L. NUUTINEN, AND A. PEKKARINEN \\ From the Departments of Forensic Medicine and Anaesthesiology, University of Oulu and Department of \\ Pharmacology, Institute of Biomedicine, University of Turku, Finland
}

SUMMARY Plasma concentrations of adrenaline, noradrenaline, and free fatty acids were measured at different stages of cardiac operations in which hypothermia and bypass were used.

The rise of adrenaline, noradrenaline, and free fatty acid concentrations in plasma is consistent with the concept that these are important compounds in stress situations such as hypothermia and surgical operations. There is a more marked release of adrenaline and it may be a more specific hormone in response to hypothermia and bypass than is noradrenaline in man.

When hypothermia is threatened during exposure to cold the organism increases heat production and prevents heat elimination. One of the most important responses is sympathetic activation whereby the secretion of catecholamines from postganglionic adrenergic nerve endings and adrenal medulla is increased. It is thought that noradrenaline is the dominant calorigenic catecholamine. Reports on humans have indicated that urinary excretion of noradrenaline in cold has increased more than that of adrenaline (Kang et al., 1970; Wilkerson et al., 1974). There are also reports which describe a more marked proportional increase of adrenaline in man (Arnett and Watts, 1960; Wilson et al., 1970; Lamke et al., 1972). It has been observed that the body temperature in a cold environment is only $0.5^{\circ} \mathrm{C}$ less than in a warm one (Lamke et al., 1972). This led us to think that perhaps in humans adrenaline could be the more important catecholamine in thermoproduction or as a stress hormone. Because previous reports have dealt mainly with the urinary excretion of catecholamines we have studied plasma levels.

Elevated concentrations of catecholamines have been detected in the urine of victims of fatal hypothermia, and the problem of catecholamine excretion in a cold environment has also some practical forensic importance (Hirvonen, 1976). Since at present hypothermia as a cause of death must be determined by exclusion this finding could serve as the basis for developing a diagnostic test. To avoid

Received for publication 21 December 1977 the disturbing effects of postmortem autolysis a preliminary investigation was undertaken in patients undergoing cardiac operations with different degrees of hypothermia but with a comparable degree of surgical trauma. Thus the secretion of catecholamines could be followed in relation to body temperature. As additional markers of the effect of catecholamines the plasma concentrations of free fatty acids and of glucose were measured. Free fatty acids are important as fuel on exposure to cold. Because of the administration of $5 \%$ glucose infusion to the patients the glucose values were, however, not informative.

\section{Material and methods}

\section{SUBJECTS}

The present paper deals with 50 patients who underwent surgical operations. They were divided into four main groups. The hypothermia groups consisted of patients undergoing three types of cardiac operations in which the body temperature was lowered below $35.5^{\circ} \mathrm{C}$. Initially, the patients were allowed to cool without any active measures. The lowering of the body temperature started after premedication and was further lowered under anaesthesia and especially when a large incision was made. The hypothermia was accomplished by cooling the blood in the heart-lung machine. The groups were as follows: $1-13$ patients undergoing a repair operation for atrial septal defect. This group was further divided into two subgroups: those with an oesophageal temperature above $35^{\circ} \mathrm{C}$ and those below $35^{\circ} \mathrm{C}$; 
2-12 patients undergoing aortic valve replacement; 3-6 patients undergoing mitral valve replacement; 4-19 control patients who underwent general surgical procedures such as operations for varices (3 subjects), cholecystectomy (7), hernia repair (6), breast tumour excision (2), and circumcision (1). This group was also divided into two subgroups on the basis of the lowest rectal temperature during the operations: rectal temperatures over $36^{\circ} \mathrm{C}(11$ subjects) and below $36^{\circ} \mathrm{C}$ (8 subjects).

\section{MEASUREMENT OF BODY TEMPERATURE}

The changes of body temperature at the different stages of operation in each group are shown in the Table. The rectal and oesophageal temperatures were monitored with an Ellab thermistor (Electrolalaboratoriet, Copenhagen). The monitoring of oesophageal temperature used in the cardiac operations had the benefit of revealing rapid changes of temperature. Changes of rectal temperature are slower but in operations without cardiopulmonary bypass this type of monitoring is satisfactory. Because measuring the oesophageal temperature involves a slight risk of vagal irritation its use was restricted.

\section{ANAESTHESIA}

All the general surgery patients received $1 \mathrm{mg} / \mathrm{kg}$ pethidine intramuscularly (im) and some received $10 \mathrm{mg}$ diazepam im in addition to the pethidine as premedication. Patients for cardiac surgery received $10-15 \mathrm{mg}$ diazepam im and $1 \mathrm{mg} / \mathrm{kg}$ pethidine im or 10-15 morphine im as premedication. General anaesthesia was started with thiomebumalum 5 $\mathrm{mg} / \mathrm{kg}$ intravenously (iv) in the general surgical procedures and atrial septal defect operations. An average dose of $100 \mathrm{mg}$ morphine (ranges: aortic valve replacement $40-160 \mathrm{mg}$ and mitral valve replacement $80-130 \mathrm{mg}$ ) and $25-50 \mathrm{mg}$ thiomebumalum iv was administered in the aortic valve replacement and mitral valve replacement operations. Pancuronium (Pavulon ${ }^{R}$ ) or alcuronium (Alloferin $^{R}$ ) intravenously were used as the relaxant in each group. The patients received $0 \cdot 25-1 \cdot 0 \%$ halothane during anaesthesia when needed. The analgesics employed were either morphine, Thalamonal ${ }^{\mathrm{R}}$ ( $2.5 \mathrm{mg}$ droperilod and $0.08 \mathrm{mg} / \mathrm{ml}$ phentanyl), or phentanyl citrate alone. Engström or UR respirators were used for controlled ventilation. During cardiac operations the maintenance of normocapnia was monitored by blood gas analyses at 30-minute intervals.

\section{PERFUSION AND FLUID THERAPY}

The general surgical patients had $5 \%$ glucose in water with 51 mmol sodium chloride per litre as intravenous infusion. The cardiac surgery patients had $5 \%$ glucose as infusion, $500-700 \mathrm{ml} / \mathrm{m}^{2}$ of body surface on the day of operation, and $40 \mathrm{mmol}$ potassium and sodium were given routinely per day.

The Rygg-Kyvsgaard heart-lung machine with bubble oxygenator was used. The oxygenator was primed with a mixture of $1000 \mathrm{ml}$ of fresh heparinised blood and $1000 \mathrm{ml}$ of $3.5 \%$ gelatine solution (Haemaccel ${ }^{R}$ ); 30 mmol sodium bicarbonate and 10000 units of aprotinine (Trasylol ${ }^{R}$ ) were added. Flow rates were maintained at $2 \cdot 4-2 \cdot 61 / \mathrm{m}^{2}$ of body surface area during perfusion.

\section{THE SAMPLES}

In the cardiac surgery groups venous blood specimens were taken before the induction of anaes-

Table Details of patients investigated

\begin{tabular}{|c|c|c|c|c|c|c|c|c|c|c|c|}
\hline \multirow[t]{2}{*}{ Group } & \multirow[t]{2}{*}{$n$} & \multirow[t]{2}{*}{$\begin{array}{l}\text { Sex } \\
F / M\end{array}$} & \multirow[t]{2}{*}{$\begin{array}{l}\text { Age } \\
\text { (years) }\end{array}$} & \multirow[t]{2}{*}{$\begin{array}{l}\text { Weight } \\
(k g)\end{array}$} & \multirow[t]{2}{*}{$\begin{array}{l}\text { Anaesthesia } \\
(\text { min })\end{array}$} & \multirow[t]{2}{*}{$\begin{array}{l}\text { Bypass } \\
\text { (min) }\end{array}$} & \multicolumn{5}{|c|}{$\begin{array}{l}\left.\text { Temperature }{ }^{\circ} \mathrm{C} \text { (oesophageal or rectal, }, \mathrm{R}\right) \text { and mean arterial pressure } \\
(\mathrm{mmHg})\end{array}$} \\
\hline & & & & & & & $\boldsymbol{A}$ & $B$ & $C$ & $D$ & $E$ \\
\hline \multirow{2}{*}{$\begin{aligned} 1 \mathrm{ASD} & >35^{\circ} \mathrm{C} \\
& <35^{\circ} \mathrm{C}\end{aligned}$} & 5 & $4 / 1$ & $32 \cdot 3 \pm 14 \cdot 2$ & $61 \cdot 6 \pm 9 \cdot 5$ & $204 \cdot 0 \pm 12 \cdot 5$ & $28.8 \pm 7.9$ & \multirow{4}{*}{$\begin{array}{l}35.8 \pm 0.48 \\
86.0 \pm 5.5 \\
35.8 \pm 0.52 \\
82.5 \pm 9.9 \\
36.6 \pm 0.53 \\
91.4 \pm 15.1 \\
35.9 \pm 1.04 \\
78.3 \pm 24.8\end{array}$} & \multirow{4}{*}{$\begin{array}{l}35.4 \pm 0.49 \\
95.0 \pm 6.1 \\
34.8 \pm 0.92 \\
90.0 \pm 6.3 \\
35.4 \pm 0.69 \\
86.4 \pm 17 \cdot 2 \\
35.4 \pm 0.73 \\
88.3 \pm 9.8\end{array}$} & \multirow{4}{*}{$\begin{array}{l}35.2 \pm 0.65 \\
64.0 \pm 11.9 \\
34.5 \pm 1.08 \\
52.5 \pm 2.6 \\
34.0 \pm 1.35 \\
54 \cdot 1 \pm 10.2 \\
33.7 \pm 0.75 \\
61.7 \pm 12.9\end{array}$} & \multirow{4}{*}{$\begin{array}{l}35.3 \pm 0.22 \\
65.0 \pm 7.9 \\
33.5 \pm 1.69 \\
70.8 \pm 9.2 \\
31.6 \pm 0.64 \\
84.1 \pm 11 \cdot 8 \\
31.9 \pm 1 \cdot 70 \\
74.2 \pm 9.2\end{array}$} & \multirow{4}{*}{$\begin{array}{l}37 \cdot 5 \pm 0 \\
78 \cdot 0 \pm 8 \\
37 \cdot 6 \pm 0 \\
80 \cdot 8 \pm \\
37 \cdot 7 \pm 0 \\
76 \cdot 4 \pm 8 \\
37 \cdot 7 \pm 0 \\
72 \cdot 5 \pm 6\end{array}$} \\
\hline & 6 & $0 / 6$ & $30 \cdot 8 \pm 14 \cdot 5$ & $71 \cdot 5 \pm 13 \cdot 5$ & $250.0 \pm 55.4$ & $41 \cdot 8 \pm 21 \cdot 8$ & & & & & \\
\hline 2 AVR & 11 & $2 / 9$ & $39 \cdot 8 \pm 8 \cdot 87$ & $70 \cdot 7 \pm 6 \cdot 40$ & $351.9 \pm 76.9$ & $139 \cdot 1 \pm 36 \cdot 7$ & & & & & \\
\hline 3 MVR & 6 & $4 / 2$ & $49 \cdot 2 \pm 5 \cdot 11$ & $66 \cdot 8 \pm 14 \cdot 3$ & $289 \cdot 2 \pm 26 \cdot 5$ & $97 \cdot 8 \pm 16 \cdot 5$ & & & & & \\
\hline $\begin{array}{l}\text { Gen. surg. } \\
<36^{\circ} \mathrm{C}\end{array}$ & 8 & $5 / 3$ & $42 \cdot 6 \pm 9 \cdot 88$ & $67.5 \pm 13.0$ & $98.8 \pm 26.9$ & & \multirow{2}{*}{$\begin{array}{l}35.9 \pm 0.20_{R} \\
92 \cdot 5 \pm 17 \cdot 9 \\
36.3 \pm 0.23_{R} \\
97.0 \pm 17.0\end{array}$} & \multirow{2}{*}{$\begin{array}{l}35 \cdot 8 \pm 0.69_{R} \\
88 \cdot 1 \pm 14 \cdot 1 \\
36 \cdot 3 \pm 0 \cdot 21_{R} \\
89.1 \pm 13.6\end{array}$} & \multirow{2}{*}{$\begin{array}{l}35 \cdot 4 \pm 0 \cdot 16_{R} \\
81 \cdot 3 \pm 12 \cdot 5 \\
36 \cdot 2 \pm 0 \cdot 28_{R} \\
80 \cdot 5 \pm 14 \cdot 0\end{array}$} & & $37 \cdot 0 \pm$ \\
\hline$>36^{\circ} \mathrm{C}$ & 11 & $5 / 6$ & $40 \cdot 9 \pm 14 \cdot 7$ & $70 \cdot 8 \pm 11 \cdot 5$ & $110 \cdot 0 \pm 39 \cdot 2$ & & & & & & $36 \cdot 7 \pm$ \\
\hline
\end{tabular}

Hypothermia groups: $\mathbf{A}=$ before induction of anaesthesia, $\mathrm{B}=$ before beginning of bypass, $\mathrm{C}=$ after beginning of bypass, $\mathrm{D}=$ lowest body tempera腒e during bypass, $\mathrm{E}=$ next morning

ASD = atrial septal defect correction, AVR = aortic valve replacement, MVR = mitral valve replacement

General surgery (control) groups: $A=$ before induction of anaesthesia, $B=2-3$ minutes after surgical incision, $C=$ before end of operation, $E$ Values $=$ mean \pm SD 
thesia, before the beginning of bypass, after the beginning of bypass, at the deepest hypothermia during bypass, and on the next morning.

In the general surgery group venous blood specimens were drawn before induction of anaesthesia, after surgical incision, before the end of operation, and on the next morning. The rectal temperature was monitored during the same time periods.

\section{Methods}

For the determination of adrenaline and noradrenaline $15 \mathrm{ml}$ blood was withdrawn into a centrifuge tube containing $1.5 \mathrm{ml}$ of $1 \%$ disodium-ethylenediamine tetra-acetic acid in $0.9 \%$ sodium chloride solution and carefully shaken to prevent blood clotting. The specimen was centrifuged within one hour. During this time it was kept in ice-water. To $5.5 \mathrm{ml}$ of plasma $1.5 \mathrm{ml}$ of $15 \%$ trichloroacetic acid was added and kept at $-20^{\circ} \mathrm{C}$ to $-15^{\circ} \mathrm{C}$. Adrenaline and noradrenaline were adsorbed from the supernatant onto $0.8 \mathrm{~g} \mathrm{Al}_{2} \mathrm{O}_{3}$ at $\mathrm{pH} 8.5$, and after five washings of $\mathrm{Al}_{2} \mathrm{O}_{3}$ (twice with $2 \% \mathrm{NA}_{2} \mathrm{HPO}_{4}$ and three times with distilled water), the catecholamines were eluted with $1.5 \mathrm{ml}$ of $0.2 \mathrm{~N}$ hydrochloric acid in $9 \% \mathrm{NaH}_{2} \mathrm{PO}_{4}$ (anhydrous) [Note: the concentration of $\mathrm{HCl}$ as well as the amount of $\mathrm{Al}_{2} \mathrm{O}_{3}$ are twice that in the method for urine] (Pekkarinen, 1969). In this method both the proteinbound and free catecholamines are extracted into the trichloroacetic acid, as shown in earlier tests. For the fluorimetric determination adrenaline and noradrenaline standards $(0 \cdot 5,1 \cdot 0,2 \cdot 0,5 \cdot 0$, and $10 \cdot 0$ $\mu \mathrm{g} / 1)$ are added to human plasma at the beginning of each series of assays to obtain a standard curve using an Aminco-Bowman spectrophotofluorimeter. The mean intensity of the specific fluorescence of the adrenaline and noradrenaline standards $( \pm$ SEM) in plasma are shown in Figure 1.

Free fatty acids in $50 \mu 1$ of plasma were determined according to Laurell and Tibbling (1967). This method is based on the formation of free fatty acidcopper soaps. Free fatty acids were extracted with chloroform-heptane-methanol. Silicic acid was used to eliminate interference by the phospholipids. Palmitic acid standards were treated in the same way. Supernatants were transferred to test tubes containing copper-trichloroacetic acid solution, and diphenylcarbazide was used for the colorimetric assay at $550 \mathrm{~nm}$.

\section{Results}

CATECHOLAMINES

Each cardiac operation group with hypothermia and

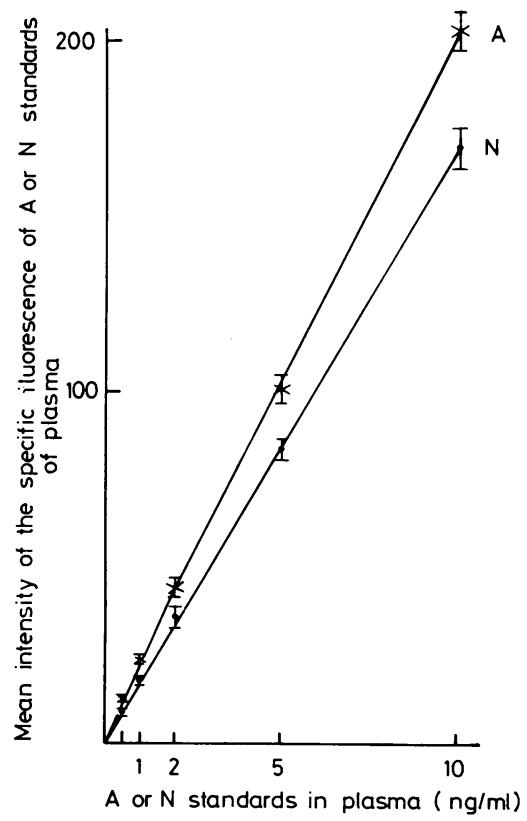

Fig. 1 Mean intensity of specific fluorescence of added adrenaline $(A)$ and noradrenaline $(N)$ standards $(0 \cdot 5-10$ $\mathrm{ng} / \mathrm{ml}$ of plasma in 10 series of determinations \pm SEM).

bypass showed a distinct and significant elevation of the mean adrenaline values in plasma from the preoperative levels (Figs 2 and 3). In the atrial septal defect group the mean adrenaline value rose from $0.05 \pm 0.09 \mathrm{ng} / \mathrm{ml}$ to $1.57 \pm 0.68 \mathrm{ng} / \mathrm{ml}$ when the body temperature stayed above $35^{\circ} \mathrm{C}$ (mean of lowest rectal temperature, $35 \cdot 3^{\circ} \mathrm{C}$ ) and from $0 \cdot 11 \pm$ $0.15 \mathrm{ng} / \mathrm{ml}$ to $3.63 \pm 3.29 \mathrm{ng} / \mathrm{ml}$ when the temperature dropped below $35^{\circ} \mathrm{C}$ (mean of lowest rectal temperature, $33.5^{\circ} \mathrm{C}$ ). The rise was from $0.13 \pm 0.23$ $\mathrm{ng} / \mathrm{ml}$ to $1.80 \pm 0.90 \mathrm{ng} / \mathrm{ml}$ in the aortic valve replacement group although the mean of lowest rectal temperature was as low as $31.6^{\circ} \mathrm{C}$. In the mitral valve replacement group (mean of lowest rectal temperature $36.9^{\circ} \mathrm{C}$ ) the change was from $0.17 \pm 0.14 \mathrm{ng} / \mathrm{ml}$ to $1.09 \pm 0.65 \mathrm{ng} / \mathrm{ml}$.

The respective elevations of noradrenaline values in the above-mentioned groups were:

from $0.83 \pm 0.36 \mathrm{ng} / \mathrm{ml}$ to $1.12 \pm 0.31 \mathrm{ng} / \mathrm{ml}$ from $0.35 \pm 0.38 \mathrm{ng} / \mathrm{ml}$ to $1.54 \pm 1.37 \mathrm{ng} / \mathrm{ml}$

from $0.64 \pm 0.34 \mathrm{ng} / \mathrm{ml}$ to $1.33 \pm 0.75 \mathrm{ng} / \mathrm{ml}$

from $0.75 \pm 0.37 \mathrm{ng} / \mathrm{ml}$ to $1.42 \pm 0.47 \mathrm{ng} / \mathrm{ml}$.

As absolute figures these changes are considerable since the basal concentration of noradrenaline in plasma is much higher than that of adrenaline. The elevations were statistically significant except in the atrial septal defect repairs with rectal temperatures greater than $35^{\circ} \mathrm{C}$. 


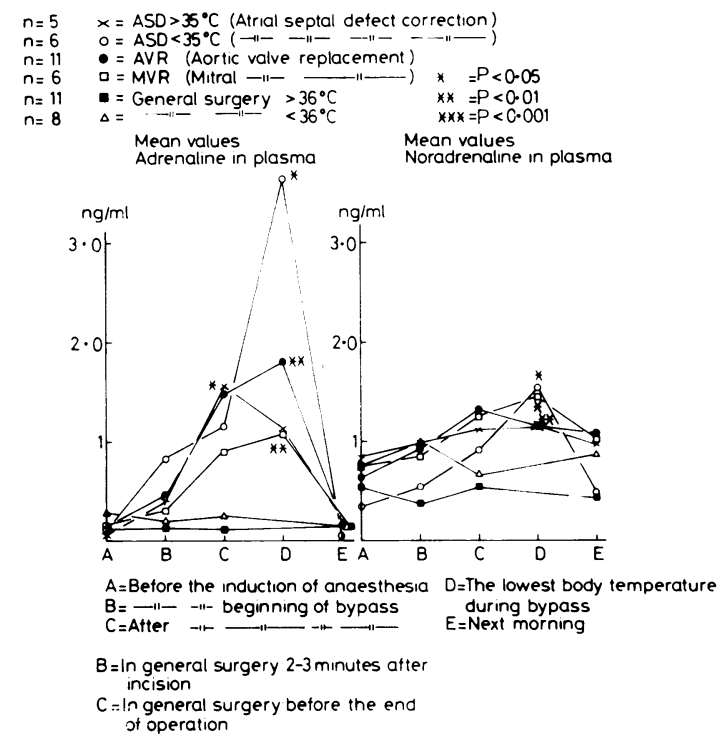

Fig. 2 Mean concentrations of adrenaline and noradrenuline ( $\mathrm{ng} / \mathrm{ml}$ of plasma) in four groups of hypothermic cardiac operations and in two groups of general surgical operations.

The highest adrenaline and noradrenaline concentrations in plasma were usually seen at lowest body temperature except adrenaline in the atrial septal group $\left(>35^{\circ} \mathrm{C}\right)$ and noradrenaline in the aortic valve replacements. In these two groups the levels were highest at the previous phase, at the beginning of bypass. Thus the elevation of the catecholamine levels coincided best with the hypothermia-bypass stage of the operation. At this stage a decrease of the mean arterial pressure was also encountered.

There were no significant changes in the plasma catecholamines during the operations in the general surgery groups whether the rectal temperature was above or below $36^{\circ} \mathrm{C}$.

\section{FREE FATTY ACIDS}

All the groups with cardiac operations showed an increase of free fatty acids (Fig. 4), which was two- to threefold of the preoperative values. The changes in the mean values ( \pm 1SD) were as follows:

ASD $>35^{\circ} \mathrm{C}$ from $0.85 \pm 0.45 \mathrm{mmol} / 1$ to $2.51 \pm 0.81 \mathrm{mmol} / 1$

ASD $<35^{\circ} \mathrm{C}$ from $1 \cdot 26 \pm 0.90 \mathrm{mmol} / 1$ to $2 \cdot 76 \pm 1.27 \mathrm{mmol} / 1$

AVR from $0.72 \pm 0.30 \mathrm{mmol} / 1$ to $2.76 \pm 0.95 \mathrm{mmol} / \mathrm{l}$

MVR from $0.91 \pm 0.49 \mathrm{mmol} / \mathrm{l}$ to $1.95 \pm 0.85 \mathrm{mmol} / 1$.

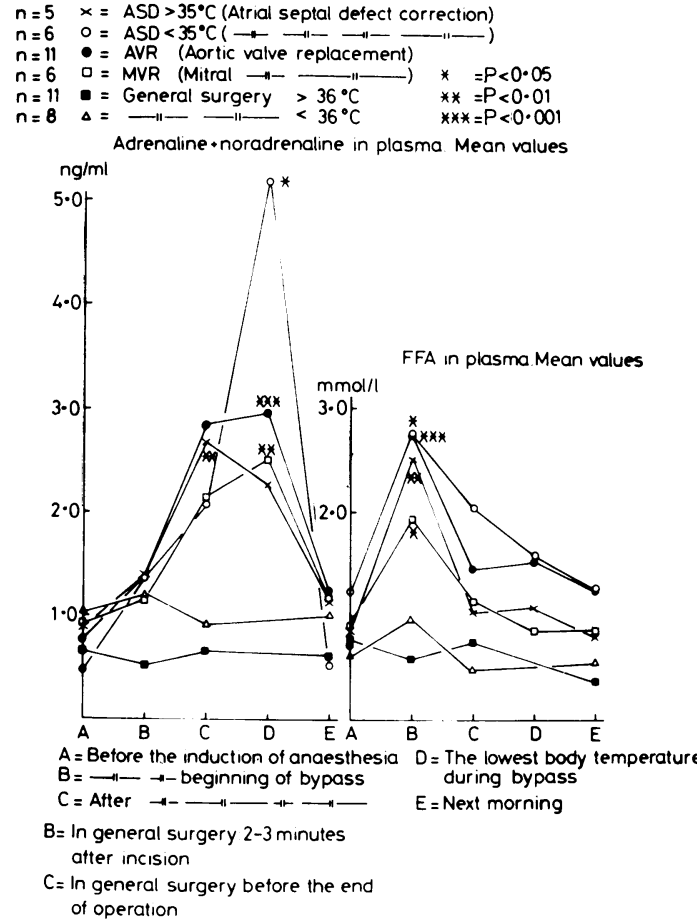

Fig. 3 Mean concentrations of adrenaline + noradrenaline (combined) $(\mathrm{ng} / \mathrm{ml})$ and free fatty acids in plasma (mmol/l) in four groups of hypothermic cardiac operations and in two groups of general surgical operations.

Highest values were seen at the prebypass stage, after which the free fatty acid concentration declined. The peaks of free fatty acid concentration appeared thus before the peaks of adrenaline and noradrenaline when the rise of adrenaline and noradrenaline concentrations had begun.

There was no change in the plasma free fatty acid concentration in the general surgery group when the 음 rectal temperature stayed above $36^{\circ} \mathrm{C}$, but a slight $\rightarrow$ nonsignificant elevation (from $0.61 \pm 0.44 \mathrm{mmol} / 1$ 을 to $0.98 \pm 0.58 \mathrm{mmol} / \mathrm{l}$ ) was noticed when the rectal temperature was less than $36^{\circ} \mathrm{C}$.

\section{Discussion}

In all groups of cardiac surgery with hypothermia and bypass, the noradrenaline concentration of $\frac{\mathbb{D}}{\overparen{D}}$ plasma was elevated. The increase of the mean $\stackrel{?}{+}$ adrenaline concentration of plasma was most 0 marked in the mitral valve replacement, atrial septal defect and aortic valve replacement groups $(4,12$, and 26 fold respectively). The increase of adrenaline and noradrenaline in plasma was not proportional to the 


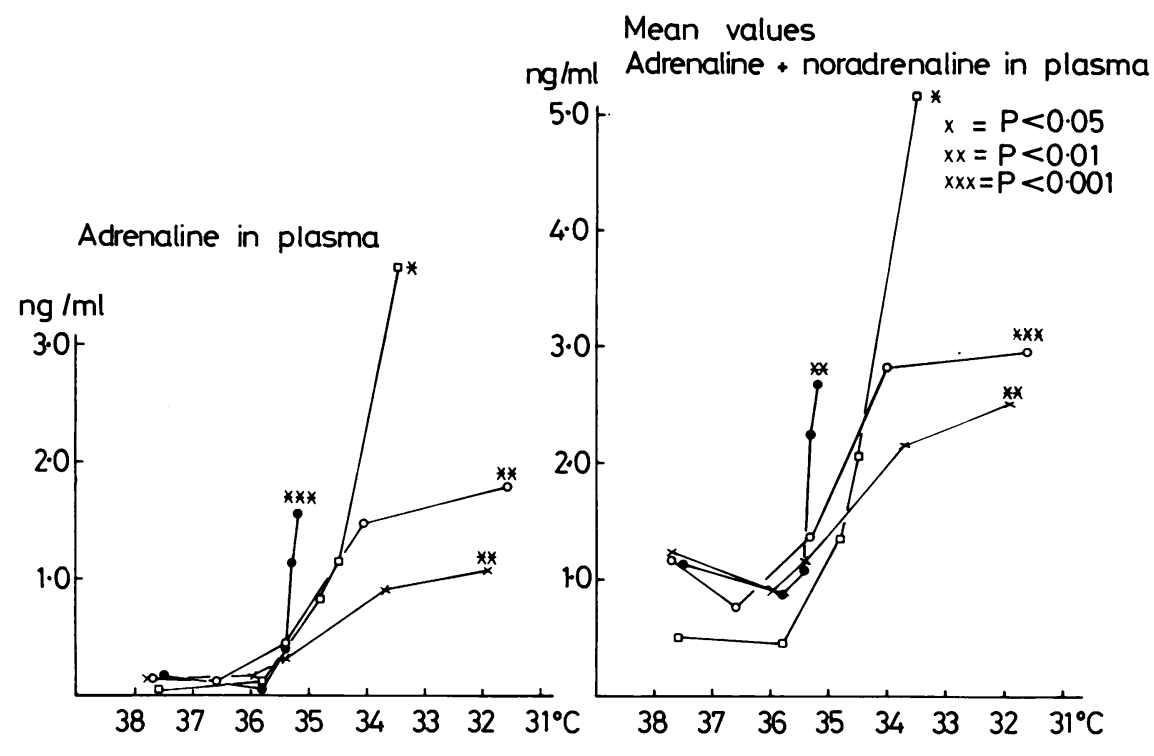

Noradrenaline in plasma

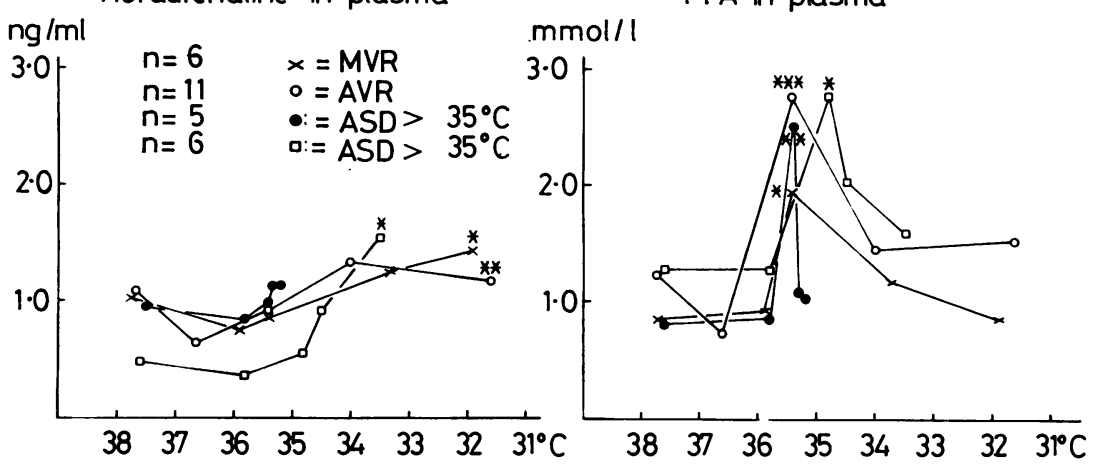

Fig. 4 Mean concentrations of adrenaline, noradrenaline, and adrenaline + noradrenaline (combined $)(\mathrm{ng} / \mathrm{ml})$ and free fatty acids in plasma $(\mathrm{mmol} / \mathrm{l})$ in four groups of hypothermic cardiac surgical operations plotted against decreasing body temperature $\left({ }^{\circ} \mathrm{C}\right)$.

degree of hypothermia. The slight lowering of the core temperature to $33.5^{\circ} \mathrm{C}$ might trigger the catecholamine response, and other factors determine its intensity, for example, bypass with hypotension.

For comparison with these levels intensive 10-20 minute ergometer exercise increases the plasma level of noradrenaline fivefold and the level of adrenaline more than twofold. Skiing over $60-90 \mathrm{~km}$ raises the plasma noradrenaline concentration twofold while the adrenaline level remains normal (Pekkarinen and
Vuori, 1969). A viva voce examination of students increases the plasma concentration of adrenaline and noradrenaline to four times the pre-examination level (Pekkarinen, 1977, personal communication).

Administration of morphine to fasting rats increases the urinary excretion of adrenaline and noradrenaline (Gunne, 1961). Bypass procedures during the replacement of mitral and aortic valves and coronary artery surgery are associated with moderate increases in noradrenaline excretion if mor- 
phine anaesthesia is used (Stanley et al., 1975a and b). In the present material, small doses of pethidine and morphine were used in all groups, and larger doses of morphine (mean $100 \mathrm{mg}$ ) against pain in all patients of aortic valve replacement and mitral valve replacement groups and $50 \mathrm{mg}$ in one patient of the atrial septal defect group. The increase of catecholamine concentrations was significant in all hypothermia-bypass groups, which thus could not be due solely to a drug effect. Nor can the stimulating effect of acidosis and hypovolaemia on catecholamine excretion be relevant in the present material because blood $\mathrm{pH}$ and volume were kept in balance with infusions.

The duration and extent of the operation can also affect the catecholamine excretion. Mitral valve replacement and aortic valve replacement operations are comparable in this sense. In our general surgery groups with minor operations, there were no increases of adrenaline or noradrenaline concentrations in plasma. Similar results have been obtained with abdominal and ophthalmic surgery but elevations of catecholamines have been noted in patients with postoperative pain (Nikki et al., 1972). However, major surgery elevates the urinary excretion of adrenaline and noradrenaline during the first two postoperative days (Halme et al., 1957).

A rise of plasma adrenaline (threefold) and noradrenaline concentration (almost double) might also be caused by bypass stress (Hine et al., 1976). In another series, the bypass and lowering of body temperature $\left(33-37^{\circ} \mathrm{C}\right)$ raised the concentration of adrenaline in plasma 15 times and of noradrenaline almost four times. At lower body temperatures $\left(25-31^{\circ} \mathrm{C}\right)$ the concentrations were lower, particularly in deep hypothermia $\left(25-27^{\circ} \mathrm{C}\right)$ (Replogle et al., 1962). In their material, the patients with a temperature of $33-37^{\circ} \mathrm{C}$ were classified as normothermic, but the catecholamine was comparable with that seen in our hypothermic groups. By present standards the body temperature of $33^{\circ} \mathrm{C}$ is hypothermic. Our results show that before the bypass procedure hypothermia $\left(33-34^{\circ} \mathrm{C}\right)$ alone is an effective stimulus for the elevation of adrenaline and free fatty acid values of plasma.

In the present material the similar decrease of mean blood pressure in all cardiac groups at the beginning of and during bypass might contribute to the increase of the catecholamine levels in plasma.

The adrenaline levels in plasma of our material are consistent with a five-fold increase of urinary excretion of adrenaline in men during exposure to cool air $\left(+15^{\circ} \mathrm{C}\right)$ (Lamke et al., 1972), as are those of Wilson et al. (1970). When unacclimatised men were exposed to $6.5^{\circ} \mathrm{C}$ for one hour, the urinary excretion of adrenaline almost doubled and nor- adrenaline increased by one-third (Arnett and Watts, 1960).

The mean urinary excretion of noradrenaline after major surgery increases moie than twofold on the two first postoperative days, and the mean excretion of adrenaline is three times higher than preoperatively (Pekkarinen, 1960; Halme et al., 1957). The excretion of adrenaline is four times higher in students during the period of matriculation examination than before, while the excretion of noradrenaline is normal (Pekkarinen et al., 1959).

Both adrenaline and noradrenaline have a similar lipolytic effect on human adipose tissue and release free fatty acids in vitro in high concentrations $(10 \mu \mathrm{g} / \mathrm{ml})($ Ebel and Brachmann, 1971) and they cause an almost identical release of glycerol from fat cells in vitro in high concentrations $\left(0.03 \times 10^{-5} \mathrm{M}\right.$, with maximal lipolytic effect at $0.3 \times 10^{-5}-3.0$ $\times 10^{-5} \mathrm{M}$ ) (Östman et al., 1969). In our material the free fatty acid levels in plasma rose two to four times from the preoperative values in the cardiac surgery groups and only slightly in those general surgery patients whose rectal temperature was lowered below $36^{\circ} \mathrm{C}$ but not in others. The free fatty acid levels in plasma rose together with the catecholamine in cardiac surgery with hypothermia and cardiac bypass. The fatty acid maximum occurred slightly ahead of that of the catecholamine in plasma, indicating that the release from the adipose tissue started at the beginning of the sympathetic stimuli. A significant increase of plasma free fatty acids has been observed previously in bypassperfusion operations (Nuutinen et al., 1977), but the findings were not then related to hypothermia.

It seems that adrenaline has a more important role in human thermogenesis than noradrenaline, because in our material the percentage increase of adrenaline concentration in plasma in hypothermia was higher than that of noradrenaline, and in man, adrenaline is a more powerful stimulus for glycogenolysis than noradrenaline (Ganong, 1975).

Elevation of adrenaline concentration in plasma in cold stress probably enhances glycogenolysis and lipolysis, producing hyperglycaemia and high free $\tilde{N}$ fatty acid concentration in the plasma. Thus adrena- $\Omega$ line would act more on thermogenesis than nor- $N$ adrenaline, which has a more potent action in thermoconservation by regulating the cutaneous blood circulation.

\section{References}

Arnett, E. L., and Watts, D. T. (1960). Catecholamine excretion in men exposed to cold. Journal of Applied Physiology, 15, 499-500.

Ebel, W., and Brachmann, K. (1971). Experimentelle 
Untersuchungen zur Lipolyse am Fettgewebe von Mensch und Meerschweinchen. Zeitschrift für die gesamte innere Medizin und ihre Grenzgebiete, 26, 30-33.

Ganong, W. F. (1975). Review of Medical Physiology, 7th ed. Lange, Los Altos, California.

Gunne, L. M. (1961). The excretion of noradrenaline and adrenaline in the urine of rats during chronic morphine administration and during abstinence. Psychopharmacologia, 2, 214-220.

Halme, A., Pekkarinen, A., and Turunen, M. (1957). On the excretion of noradrenaline, adrenaline, 17-hydroxycorticosteroids and 17-ketosteroids during the postoperative stage. Acta Endocrinologica, 24, Suppl. 32, $1-52$.

Hine, I. P., Wood, W. G., Mainwaring-Burton, R. W., Butler, M. J., Irving, M. H., and Booker, B. (1976). The adrenergic response to surgery involving cardiopulmonary bypass, as measured by plasma and urinary catecholamine concentrations. British Journal of Anaesthesia, 48, 355-363.

Hirvonen, J. (1976). Necropsy findings in fatal hypothermia cases. Forensic Science, 8, 155-164.

Kang, B. S., Han, D. S., Paik, K. S., Park, Y. S., Kim, J. K., Kim, C. S., Rennie, D. W., and Hong, S. K. (1970). Calorigenic action of norepinephrine in the Korean women divers. Journal of Applied Physiology, 29, 6-9.

Lamke, L. O., Lennquist, S., Liljedahl, S. O., and Wedin, B. (1972). The influence of cold stress on catecholamine excretion and oxygen uptake of normal persons. Scandinavian Journal of Clinical and Laboratory Investigation, 30, 57-62.

Laurell, S., and Tibbling, G. (1967). Colorimetric microdetermination of free fatty acids in plasma. Clinica Chimica Acta, 16, 57-62.

Nikki, P., Takki, S., Tammisto, T., and Jäättelä, A. (1972). Effect of operative stress on plasma catecholamine levels. Annals of Clinical Research, 4, 146-151.

Nuutinen, L., Mononen, P., Kairaluoma, M., and Tuononen, S. (1977). The effect of cardiopulmonary bypass time on plasmalipids. Annales Chirurgica et Gynaecologica Fennica, 66, 90-93.

Östman, J., Efendić, S., and Arner, P. (1969). Catecholamines and metabolism of human adipose tissue. Acta Medica Scandinavica, 186, 241-246.

Pekkarinen, A. (1960). The effect of operations and physical injury on the adrenal glands and the vegetative nervous system in man. In The Biochemical Response to Injury, edited by H. B. Stoner and C. J. Threlfall, pp. 217-268. Blackwell, Oxford.
Pekkarinen, A. (1969). Fluorometric determination of adrenaline and noradrenaline. In Regulation of the Increased Adrenomedullary Secretion by Drugs, by K. Manninen. Thesis, Turku University, Finland.

Pekkarinen, A., Castrén, O., Iisalo, E., Koivusalo, M., Laihinen, A., Simola, P. E., and Thomasson, B. (1959). The emotional effect of matriculation examinations on the excretion of adrenaline, noradrenaline, 17-hydroxycorticosteroids into the urine and the content of 17hydroxycorticosteroids in the plasma. In Biochemistry, Pharmacology, and Physiology: Second Scandinavian Summer Meeting (1959), edited by J. Järnefelt, pp. 117 137. Pergamon Press, Oxford.

Pekkarinen, A., and Vuori, I. (1969). Effect of long distance skiing and short maximal physical exercise on the vanilmandelic acid, noradrenaline, adrenaline and 17-OHCS response in the urine and plasma (Abstract). Scandinavian Journal of Clinical and Laboratory Investigations, 23, Suppl. 108, 42 (and personal communications).

Replogle, R., Levy, M., DeWall, R. A., and Lillehei, R. C. (1962). Catecholamine and serotonin response to cardiopulmonary bypass. Journal of Thoracic and Cardiovascular Surgery, 44, 638-648.

Stanley, T. H., Isern-Amaral, J., and Lathrop, G. D. (1975a). Urine norepinephrine excretion in patients undergoing mitral or aortic valve replacement with morphine anesthesia. Anesthesia and Analgesia, 54, 509-517.

Stanley, T. H., Isern-Amaral, J., and Lathrop, G. D. (1975b). The effects of morphine and halothane anaesthesia on urine norepinephrine during and after coronary artery surgery. Canadian Anaesthetists Society Journal, 22, 478-485.

Wilkerson, J. E., Raven, P. B., Bolduan, N. W., and Horvath, S. M. (1974). Adaptations in man's adrenal function in response to acute cold stress. Journal of Applied Physiology, 36, 183-189.

Wilson, O., Hedner, P., Laurell, S., Nosslin, B., Rerup, C., and Rosengren, E. (1970). Thyroid and adrenal response to acute cold exposure in man. Journal of Applied Physiology, 28, 543-548.

Requests for reprints to: Professor J. Hirvonen, Department of Forensic Medicine, University of Oulu, Kajaanintie 52 D, 90220 OULU 22, Finland. 